\title{
Video laryngoscopy in COVID-19 patients: a word of caution
}

\author{
Neha Singh, MD $\cdot$ Pamandi Bhaskar Rao, MD, PDCC, FIPM $\cdot$ Nitasha Mishra, MD, \\ DM
}

Received: 10 April 2020/Revised: 14 April 2020/Accepted: 15 April 2020/Published online: 27 April 2020

(c) Canadian Anesthesiologists' Society 2020

\section{To the Editor,}

We read with interest the informative publication by Wax et al. on the practical recommendations for critical care and anesthesiology teams caring for patients with coronavirus disease (COVID-19). ${ }^{1}$ The use of video laryngoscopy as the method of choice for airway management in patients during the COVID-19 outbreak was suggested by the authors, and various anesthesia Societies, ${ }^{2}$ in part, to increase the distance from the operator to the patient's mouth. We would like to offer several other recommendations.

A method that similarly increases the distance between the patient and operator is flexible bronchoscopic intubation (by experienced operators) under anesthesia with deep muscle relaxation. ${ }^{3}$ We would also like to emphasize that if a video laryngoscope is used, it is preferential not to use its integrated oxygen channel if present (APA Oxy Blade ${ }^{\mathrm{TM}}$; Venner Medical Pte Ltd, Singapore) as the extraneous flow of oxygen may increase aerosol generation rather than reduce it. Nor should stylets or flexible bronchoscopes have oxygen insufflated through their central channels.

Lastly, the use of regional anesthesia, when applicable, may also help to reduce the risk of aerosol generation during general anesthesia. ${ }^{4}$ We all should keep our team safe and use our resources intelligently during this COVID19 pandemic.
Conflict of interest None.

Funding statement None.

Editorial responsibility This submission was handled by Dr. Hilary P. Grocott, Editor-in-Chief, Canadian Journal of Anesthesia.

\section{References}

1. Wax RS, Christian MD. Practical recommendations for critical care and anesthesiology teams caring for novel coronavirus (2019nCoV) patients. Can J Anesth 2020. DOI: https://doi.org/10.1007/ s12630-020-01591-x.

2. World Federation of Societies of Anaesthesiologists. Coronavirus guidance for anaesthesia and perioperative care providers - 2020. Available from URL: https://www.wfsahq.org/latest-news/ latestnews/943-coronavirus-staying-safe (accessed April 2020).

3. Wong J, Lee JS, Wong TG, Iqbal R, Wong P. Fibreoptic intubation in airway management: a review article. Singapore Med J 2019; 60: 110-8.

4. Lie SA, Wong SW, Wong LT, Wong TGL, Chong SY. Practical considerations for performing regional anesthesia: lessons learned from the COVID-19 pandemic. Can J Anesth 2020. DOI: https:// doi.org/10.1007/s12630-020-01637-0.

Publisher's Note Springer Nature remains neutral with regard to jurisdictional claims in published maps and institutional affiliations. 